\title{
A note on the defence by Eurema blanda Boisduval (Lepidoptera: Pieridae) pupae in response to oviposition behaviour of the chalcid wasp Brachymeria sp. (Hymenoptera: Chalcididae)
}

Nota sobre la defensa de las pupas de Eurema blanda Boisduval (Lepidoptera: Pieridae) en respuesta al comportamiento de oviposición del calcídido Brachymeria sp. (Hymenoptera: Chalcididae)

\author{
Arajush Payra ${ }^{1}$ D
}

${ }^{1}$ Ramnagar, Purba Medinipur, West Bengal 721441, India. E-mail: arajushpayra@gmail.com

\section{ZooBank: urn:lsid:zoobank.org:pub: 548A2FB3-B589-4523-AC9D-32DD974FCD62 https: / / doi.org/10.35249/ rche.46.3.20.13}

\begin{abstract}
The defensive movements of the pupae of Eurema blanda in response to the oviposition behaviour of the chalcidid wasp Brachymeria sp. were observed in natural condition and reported here for the first time.
\end{abstract}

Key words: Butterfly, defensive movements, India, parasitoid, pupal stage.

Resumen. Se reportan y observan por primera vez en condiciones naturales los movimientos defensivos de las pupas de Eurema blanda en respuesta al comportamiento de oviposición del calcídido Brachymeria sp.

Palabras clave: Estado pupal, India, mariposa, movimientos defensivos, parasitoide.

Immobile pupal stage is the most vulnerable period in butterfly's life stage. As they can easily be predate/attacked by the vertebrate predators (voles, mice, shrews, etc.); invertebrate predators (ants, wasps, earwigs etc.) and parasitoids. However, to avoid predators and parasitoids or escaping from predations, pupa has developed many anti predator strategies ranging from camouflage, sound production to defensive toxins and physical defences (Lindstedt et al. 2019). Some of the butterfly's pupae camouflage themselves with cryptic colour, while some exhibit vivid colouration to warn the predators. Pupa of many swallowtail butterflies makes snake like hissing sounds when they disturbed (Kehimkar 2016; Dolle et al. 2018). Some species of Nymphalidiae, Lycaenidae, Riodinidae and Hesperiidae butterflies also have the ability to make noise in response to external stimuli (Dolle et al. 2018).

However, knowledge on the defensive movements executed by butterfly pupae in response to parasitoid wasps is very scanty. Cole (1959) reported intensive wiggling movements in the pupae of Aglais urticae Linnaeus, 1758 (Nymphalidae) in response to the oviposition behaviour of ichneumonid wasp. By this movements, pupae preventing the parasitoid, that tries to land on it or tries to depositing the egg inside the pupae. He also mentioned that, oviposition success of parasitoids is higher in Pararge aegeria (Linnaeus, 1758) (Nymphalidae) and Pieris brassicae (Linnaeus, 1758) (Pieridae), whose pupae are not able to perform wiggling movements as intensively as the pupae of A. urticae.

Received 17 July 2020 / Accepted 18 August 2020 / Published online 28 August 2020

Responsible Editor: José Mondaca E. 
Eurema blanda (Boisduval, 1836) is a commonly found pierid butterfly and widely distributed in Pakistan, Sri Lanka, Nepal, Bhutan, India to Myanmar, China, Thailand, Lao PDR, Cambodia, and Viet Nam (Kehimkar 2016; Inayoshi 2020). The defensive movements in the pupal stage of Eurema butterfly has never been mentioned before. Here we report and describe the defensive movements of E. blanda for the first time, in relation to the oviposition behaviour of a chalcid wasp Brachymeria sp. Brachymeria is a genus of parasitic wasp belongs to family Chalcididae. The genus consists of over 300 species and mostly parasitic on Lepidoptera.

During a field survey in Shankarpur coastal forest $\left(21^{\circ} 38^{\prime} 11.26^{\prime \prime} \mathrm{N}, 87^{\circ} 33^{\prime} 34.16^{\prime \prime} \mathrm{E}, 7\right.$ m.a.s.l.), of Purba Medinipur District, West Bengal, India, on 18.xii.2019, at 01:45 pm, a total of 71 pupae of Eurema blanda (Boisduval, 1836) were recorded on a Caesalpinia bonduc (L.) Roxb. plant. The pupae were located at different parts of the plant with 10 clutches. Only a few were placed at stem, and most of them were seen on mid rib of the plant's leaf. Some pupal clutches were close to the ground, while some were at $1 \mathrm{~m}$ height from the ground. During the time, one chalcid wasp was observed to flying around the pupal clutches, those are at $1 \mathrm{~m}$ height and exposed to the surroundings. The observations were carried out for one hour and recorded by videos and photographed. Four attempt cases by wasp to land on the pupae were observed, and three times movements were powerful enough to throw away the alighted wasp. When the wasp come very closer or tries to land on the pupa, the vertically hanging pupae performs left and right ways movement to prevent the wasp to land on it (Fig. 1).

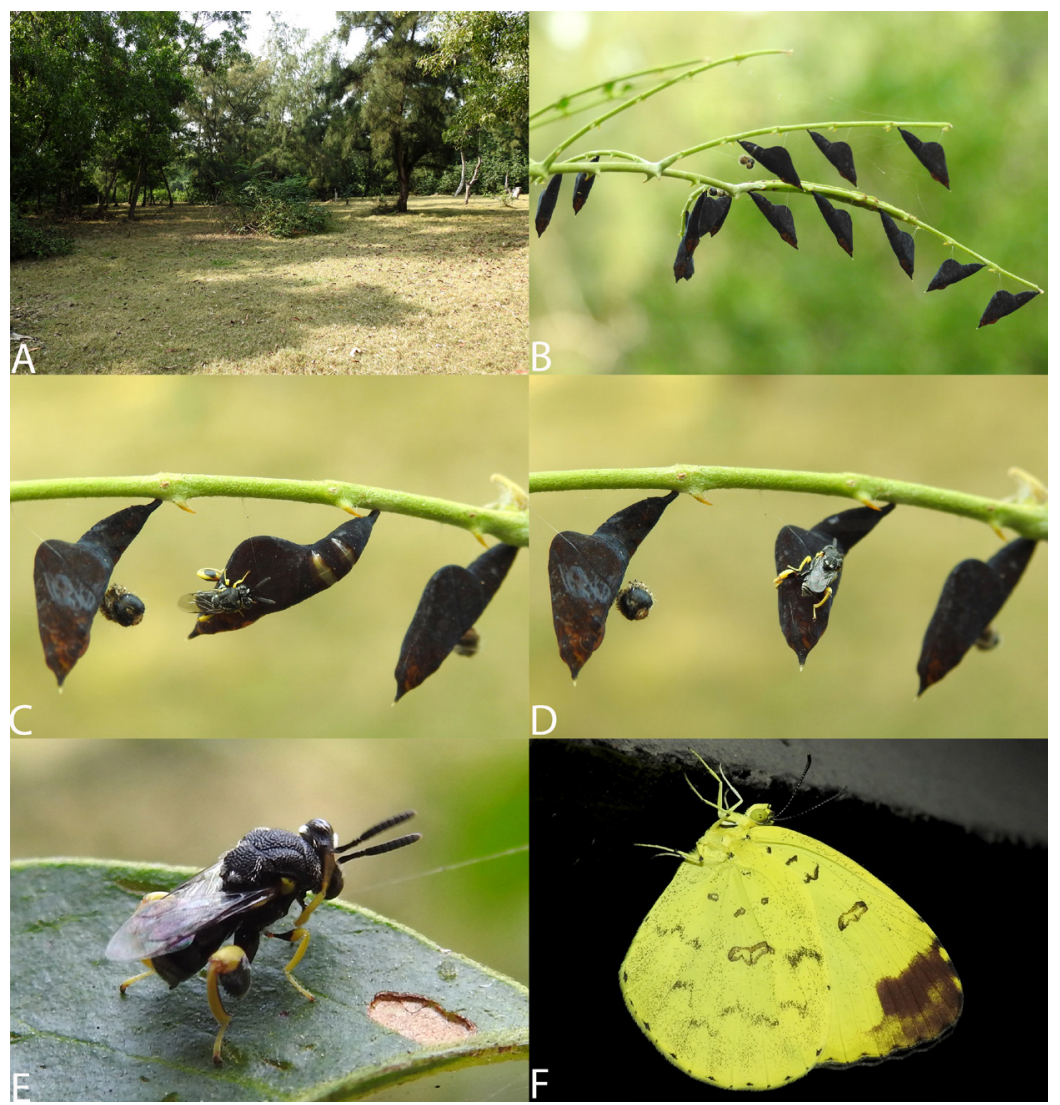

Figure 1. A. Habitat where observations were carried out. B. Pupal clutches. C \& D. Left and right ways movement of pupa in response to Brachymeria sp. E. Female Brachymeria sp. F. Newly emerged Eurema blanda from collected pupae. 
The wiggling movements of E. blanda pupae vary in response to the external stimuli. The pupae show only one or two lethargic movements when gently touched by the fingers, but shows rapid movements when the pupae came in contact with the flying wasp or when the wasp tries to land on it. The same varying movement responses were observed in case of Aglais urticae pupae by Cole (1959). Thus Dolle et al. (2018) said, "Very punctual excitation might be better than stimulation of wider areas". Indicating, the wiggling movements might have evolved in such pupae, particularly in response to the oviposition behaviour of parasitoids. Interestingly, when one pupa starts to wiggling (after approached by the wasp); the nearby pupae present in that thread also shows movements (one to two), and stays in the bent position for some time. Possibly it seems to be their alert posture.

However, during the study period, oviposition success of Brachymeria sp. on E. blanda was not studied properly. But 12 pupae were randomly collected from the different pupal clutches, of which 10 Brachymeria sp. (emerged between 27.xii.2019 to 30.xii.2019) were emerged and one E. blanda (emerged on 29.xii.2019), and one pupa remains infertile. The present report suggest the crucial need of further studies to get a complete insight into the defence behaviour of butterflies pupae, as well as the rate of oviposition success by parasitoid wasps need significant attention.

\section{Acknowledgement}

I am grateful to Dr. Ankita Gupta (ICAR-National Bureau of Agricultural Insect Resources, India) for helping in identification of chalcid wasp.

\section{Literature Cited}

Cole, L.R. (1959) On the defences of Lepidopterous pupae in relation to the oviposition behaviour of certain Ichneumonidae. Journal of the Lepidopterists'Society, 13: 1-10.

Dolle, P., Klein, P., Fischer, O.W., Schnitzler, H.U., Gilbert, L.E. and Boppré, M. (2018) Twittering pupae of papilionid and nymphalid butterflies (Lepidoptera): novel structures and sounds. Annals of the Entomological Society of America, 111(6): 341-354.

Inayoshi, Y. (2020) A Check List of Butterflies in Indo-China, chiefly from Thailand, Laos and Vietnam. http:/ / yutaka.it-n.jp (Retrieved on July, 2020)

Kehimkar, I. (2016) Butterflies of India. Bombay Natural History Society, Mumbai, xxii+ 528 pp.

Lindstedt, C., Murphy, L. and Mappes, J. (2019) Antipredator strategies of pupae: how to avoid predation in an immobile life stage?. Philosophical Transactions of the Royal Society B, 374(1783): 20190069. 